\title{
Glioma and Exosome
}

\author{
Rahimeh Rasouli $^{1, *(D)}$, Niloofar Nazeri ${ }^{1,2}$ *(D) \\ Department of Medical Nanotechnology, Tehran University of Medical Sciences, Tehran, Iran \\ Clinical Research Development Unit, Shahid Rajaee Hospital, Qazvin University of Medical Sciences, Qazvin, Iran \\ Correspondence: nina_1366_nazeri@yahoo.com (N.N.), r-rasouli@razi.tums.ac.ir (R.R.);
}

Scopus Author ID 55630317300, 55915356900

Received: 12.03.2021; Revised: 28.05.2021; Accepted: 5.06.2021; Published: 27.06.2021

\begin{abstract}
Exosomes are membrane-enclosed vesicles that contain lipids, proteins, mRNA, and microRNA. They can be a source of multiple markers of malignancy that could offer clinically valuable data. On the other hand, they can pass through the blood-brain barrier (BBB) and play an endogenous nano anticancer drug delivery vehicle for glioma. This review will discuss exosome potential in the diagnosis and novel treatment of glioma and their role in chemotherapic resistance and metastasis through an interaction with a range of host cells in the brain.
\end{abstract}

Keywords: exosome; glioma; biomarker.

(C) 2021 by the authors. This article is an open-access article distributed under the terms and conditions of the Creative Commons Attribution (CC BY) license (https://creativecommons.org/licenses/by/4.0/).

\section{Glioma}

Malignant glioma such as glioblastoma multiforme (GBM) is one of the greatest challenges for cancer patients worldwide. Gliomas based on histological characteristics are classified into four grades( I - IV). Grade IV of glioma is referred to as a glioblastoma multiforme (GBM). Glioblastoma is the most malignant grade and common primary brain tumor. This tumor, base on genomic alterations, divides into 3 to 4 distinct subclasses [1]. Diagnostic key features of GBM include vascular hyperproliferation, necrosis, cellular and nuclear atypia, poorly differentiated neoplastic astrocytes, vascular thrombosis, neoangiogenesis, abrupt mitotic activity, along with reduced apoptosis. GBM, similar to most other malignant CNS tumors, does not metastasize outside the CNS [2-5]. Average patient' survival despite typical treatments include surgery, chemotherapy with the alkylating agent temozolomide, and ionizing radiation, is about 1.5 years. So new, more effective targeted therapeutics are required $[6,7]$.

\section{Exosome}

Exosomes are membrane-enclosed and endosome-derived vesicle bodies (MVBs) with the plasma membrane, the vesicles released into the extracellular milieu are called exosomes [8-10].

\subsection{Exosome structure.}

A different group of proteins is in the exosomes; one group contains signal peptides and is secreted by the ER-Golgi pathway, but the other lacks signal peptides. The second group is called non-classically secreted proteins, probably secreted by one or more pathways [11-13]. 
Feng et al. proposed that proteins with high-ordered oligomerization and associate with the plasma membrane are sorted into exosomes [14].

Proteins have a different role in exosomes, such as fusion proteins and proteins for MVB biogenesis, such as Alix and Tumor susceptibility gene Tsg 101 [15]. Density centrifugation should be done to separate exosomes from nucleosomal fragments and protein aggregates. Immunoblotting and mass spectroscopy prove the presence of Alix and Tsg 101 in the separated fractions; suppose that these vesicles originate from MVBs [16]. Some conserved proteins exist in exosomes like heat shock proteins (HSP), CD63, and tetraspanin [17].

HSPs are the group of proteins activated in response to stresses [18]. Studies have shown that anticancer drugs stimulate the release of exosomes and HSPs from human hepatocellular carcinoma cells [19]. More studies revealed that exosomes with HSP could cause an anti-tumor response in a murine model in an MHC-dependent manner [20].

Of interest, among different proteins in exosomes, pathogenic proteins can exist too. This kind of protein is secreted via exosomes and causes trans-synaptic exchange, and in this way, disease propagates from the peripheral nervous system to CNS. Alzheimer's, Prion, Parkinson's disease are examples of neurodegenerative diseases related to exosomes [21].

Studies have exhibited that the different proteins from the Rab family act as key regulators. As Rab 27 is involved in exosome secretion and cancer progression and tumor promotion, it is acceptable to suggest that components that have a role in the exosome secretion pathway can also participate in tumor biology [22].

Two types of lipids exist in exosomes. The first group is conserved, and the second one is dependent on cell type [23]. Lipids play a role in cell communication and give shape to exosomes [24]. Exosomes related to lipid rafts are enriched in lipids like sphingolipids, cholesterol, ceramide, and glycerophospholipids [25]. Different phospholipases, arachidonic acids, and prostaglandins are signaling mediators present in exosomes [26, 27].

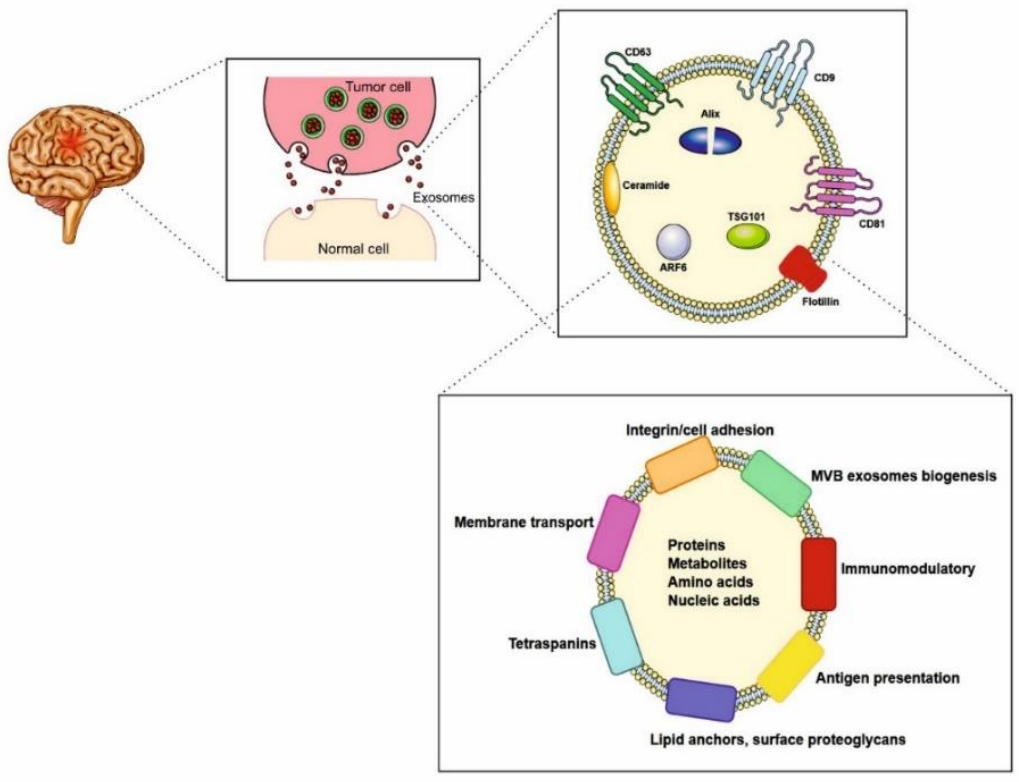

Figure 1. Schematic representation of biogenesis of exosomes (a), biomarkers for glioma-derived exosomes(b). The overall content of exosomes includes DNA(mtDNA, dsDNA,ssDNA Viral DNA), non-coding RNAs (ncRNAs: miRNAs, circRNA, piRNAs, tsRNA, and lncRNA), proteins ( cytoskeletal, HSP, a nuclear enzyme, RNA binding apoptotic signal transducers), amino acids and metabolites (c).

Previous studies have revealed that exosomes are enriched with non-coding RNAs (ncRNAs), including microRNA (miRNAs), circular RNA (circRNA), piwi-interacting RNAs 
(piRNAs), tRNA-derived small non-coding RNA (tsRNA), and long-noncoding RNA (lncRNA), which play key roles especially in various cancers [28-33]. Exosomal lncRNAs stimulate drug resistance, metastasis, and angiogenesis in cancerous cells - the biological functions of exosomal ncRNAs in glioma. The structure of glioma-derived exosome and exosomal biomarkers are shown in Figure 1. The specific roles and mechanisms of exosomal ncRNA in glioma progression are summarized in Table 1. According to these functions of ncRNAs, they have been proposed as potential biomarkers and therapeutic agents in glioma.

Table 1. The biological functions of exosomal ncRNAs in glioma. Reproduced with permission [34].

Copyright 2020, Springer.

\begin{tabular}{|c|c|c|c|}
\hline NcRNAs & Parent cell & Target cell & Biological function \\
\hline miR-221 & U87MG & SHG-44 & $\begin{array}{l}\text { Promote proliferation, migration, and } \\
\text { TMZ resistance }\end{array}$ \\
\hline IncRNA-ATB & Glioma cells & Normal human astrocytes & Promote invasion \\
\hline miR-148a & Glioma cells & Glioma cells & Promote proliferation and metastasis \\
\hline$\underline{\mathrm{miR}-451 / \mathrm{miR}-21}$ & Glioma cells & Microglia/macrophages & $\begin{array}{l}\begin{array}{l}\text { Promote proliferation and immune } \\
\text { suppression }\end{array} \\
\end{array}$ \\
\hline miR-1587 & Mesenchymal Stem Cells & Glioma Stem-like Cells & Increase tumorigenicity \\
\hline$\underline{\operatorname{miR}-1}$ & Glioblastoma cells & \begin{tabular}{|l} 
Endothelial cells and \\
glioblastoma cells
\end{tabular} & $\begin{array}{l}\text { Inhibit angiogenesis, invasion, and } \\
\text { neurosphere formation }\end{array}$ \\
\hline miR-124 & Mesenchymal stem cells & glioblastoma cells & $\begin{array}{l}\text { Inhibit proliferation, migration and } \\
\text { confer chemosensitivity }\end{array}$ \\
\hline miR-302-367 & Glioma stem-like cells & Glioblastoma cells & Inhibit growth \\
\hline miR-7 & Mesenchymal stem cells & Glioblastoma cells & Increase apoptosis and suppress growth \\
\hline miR-584 & Mesenchymal stem cells & Glioma cells & Suppress tumor progress \\
\hline miR-146b & Marrow stromal cells & Gliosarcoma cells & Reduce glioma growth in vivo \\
\hline miR-124a & Mesenchymal stem cells & Glioma stem cell & Antiglioma agent \\
\hline miRNA-199a & Mesenchymal stem cells & Glioma cells & $\begin{array}{l}\text { Inhibit proliferation, invasion and } \\
\text { enhance chemosensitivity }\end{array}$ \\
\hline miR-375 & Marrow stromal cells & Glioma cells & Inhibit glioma progression \\
\hline IncRNA- HOTAIR & Glioblastoma cells & Endothelial cells & Promote angiogenesis \\
\hline lincRNA-CCAT2 & Glioma cells & Endothelial cells & Promote angiogenesis \\
\hline lincRNA- POU3F3 & Glioma cells & Endothelial cells & Promote angiogenesis \\
\hline miR-26a & Glioma stem cells & Endothelial cells & Promote angiogenesis \\
\hline miR-21 & Glioma stem cells & Endothelial cells & Promotes angiogenesis \\
\hline miR-9 & Glioma cells & Endothelial cells & Promote tumorigenesis and angiogenesis \\
\hline miR-10a, miR-21 & Hypoxic glioma cells & $\begin{array}{l}\text { Myeloid-derived } \\
\text { suppressor cells }\end{array}$ & $\begin{array}{ll}\text { Mediate immunosuppressive } \\
\text { microenvironments }\end{array}$ \\
\hline miR-29a, miR-92a & Hypoxic glioma cells & $\begin{array}{l}\text { Myeloid-derived } \\
\text { suppressor cells }\end{array}$ & $\begin{array}{l}\text { Mediate immunosuppressive } \\
\text { microenvironments }\end{array}$ \\
\hline miR-1246 & Hypoxic glioma cells & Macrophages & $\begin{array}{ll}\text { Mediate } & \text { immunosuppressive } \\
\text { microenvironment }\end{array}$ \\
\hline miR-21 & Glioma cells & Microglia & $\begin{array}{ll}\text { Mediate } & \text { immunosuppressive } \\
\text { microenvironment }\end{array}$ \\
\hline miR-151a & TMZ-resistant glioblastoma cells & $\begin{array}{l}\text { TMZ-sensitive } \\
\text { glioblastoma cells }\end{array}$ & Enhances chemosensitivity to TMZ \\
\hline lncRNA-SBF2- AS1 & TMZ-resistant glioblastoma cells & $\begin{array}{l}\text { Chemo-responsive } \\
\text { glioblastoma cells }\end{array}$ & Enhances chemoresistance to TMZ \\
\hline circATP8B4 & Radioresistant glioma cells & Normal glioma cells & Promote cell radioresistance \\
\hline miR-301a & Hypoxic glioma cells & $\begin{array}{l}\text { Normoxia-cultured } \\
\text { glioma cells }\end{array}$ & Promote radiation resistance \\
\hline
\end{tabular}

\section{Brain and Exosomes}

The brain's function depends on neurons' ability to modulate each other via synapses change in the number of postsynaptic neurotransmitter (NT) receptors or the amount of NT released from pre-synaptic neuron effect on synaptic efficacy [35]. Scientists recently observed that secretory exosomes in the nervous system contain miRNA[36]. miRNAs silence target genes in receiving cells and so cause long changes in specific synapses. Propagation of pathological alterations throughout the brain is possible by exosome transfer [21, 37, 38]. 
Exosomes from GBM cells enriched in proteins and RNAs relate to tumor growth promotion, stimulation of angiogenesis, suppression of the immune response to tumor antigens, modulation of normal cellular phenotypes, and chemotherapeutic drugs ejection from tumor cells $[10,34,39-42]$.

\subsection{Secretion of exosomes by neurons.}

Chivet and coworkers have suggested that a good activator for exosome secretion is calcium entry through synaptic NMDA-receptor [36]. In other words, the release is regulated by depolarization [43].

Faure et al., by using proteomic methods, have shown that neuronal exosomes are similar to exosomes of non-neuronal cell types. However, neurons have some specific components like AMPA receptor subunit GluR2/3 and neuronal cell adhesion molecule L1, which is inclusively expressed by neurons [43].

\section{Mechanisms of Uptake of Tumor Vesicle by Cells}

To internalize and uptake exosomes, cells use more different pathways, such as inducing the formation of tunneling nanotubes in the plasma membrane or phagocytosis [14, 44]. Internalization of glioma exosomes mediates by heparan sulfate proteoglycans (HSPGs) function as receptor exosomes in recipient cells [45, 46].

\section{Exosome and Glioma}

\subsection{Exosome role in metastasis.}

Tumor cells influence their surrounding normal cells to provide conditions in which tumor cells grow, invade, chemoresistant, evade the immune system, and financially metastasis [47-50]. Studies demonstrated that matrix metalloproteinases (MMPs) and an extracellular MMP inducer on the exosome surface destroy the extracellular matrix and facilitate tumor cells' attack into neighboring normal brain cells [51].

Tumors activate the immune-suppressive pathway to dominate the immune system and progress [52]. Recent studies have shown that communication between tumor cells is very important [53]. Tumor cells of glioblastoma cultured as monolayers. Cultured cells produce exosomes at early and late passages(1-15 passages). Exosomes of different sizes (50-500 nm) covered the tumor cells [54]. Reports have revealed that secretory exosomes mediate the communication of neurons and astrocytes [55]. Exosomes contained RNA and protein in a ratio of about 1:80. They contain high concentrations of angiogenic factors promote angiogenic cascades such as VEGF, TIMP-1, IL-6, IL-8, and angiogenin and various mRNA and miRNA with different size [54]. Experiments have proved that glioblastoma-derived exosomes initiate angiogenesis in brain endothelial cells. Skog et al. have shown that angiogenic proteins at least partially mediate exosomes' angiogenic influence. They suggest that the tumor-derived exosomes can change their surrounding normal cells by changing cell translation. This suggestion is a contest with proteins which are export to the outer cellular milieu by exosomes can be either tumor suppressor or tumor promoters [56]. Likewise, glioblastoma exosomes can stimulate angiogenesis in the brain's normal endothelial cells and the proliferation of other glioma cells [54]. Exosome-mediated angiogenesis was done by upregulation of proteaseactivated receptor-2 in epithelial cells [57]. Glioblastoma exosomes contain angiogenic 
proteins such as angiogenin, EGF $\alpha$, VEGF, TIMP-1, IL-6, IL-8, TIMP-2 [54]. On the other hand, exosomes act as escape routes for miRNA and proteins from cells of cancer origin to a distant location and conclusively cause metastasis [58]. Recent studies displayed that hypoxia increases exosome secretion in different kinds of tumors [59-64]. Kucharzewska et al. demonstrate that exosomes derived from GBM cells that were in hypoxic conditions can induce phenotype change in endothelial cells to secret some cytokines and growth factors [65]. They also have exhibited that exosomes, as mediators, communicate between malignant and vascular cells, such as pericyte and ECs. This communication ends in tumor vasculature phenotype alteration [65].

Park et al. have demonstrated that cells in a hypoxic microenvironment increase angiogenic pathways. On the other hand, increased exosome secretion in hypoxic status promotes potential metastatic 1 [66]. Experiments on a highly malignant glioma were consistent with Park group results [67]. In other words, tumor cells in hypoxia status adapt to this condition by secreting exosomes to facilitate metastasis by stimulating angiogenesis [66].

\subsection{Exosome role in cancer resistance.}

Acquired resistance to cancer therapy remains a big problem [68]. Experiments have shown that cells release exosomes containing membrane attack complex (MAC) and Mortalin to block membrane lysis by the complement system [69].

Resistant glioblastoma cells express miRNA-9. Other studies have shown that miRNA9 molecules play a role in the resistance of GBM cells to Temozolomide (TMZ) by increasing p-glycoprotein. Experiment results indicate that TMZ increased vesicular secretion from GBM cells and also increase the exosomal miRNA-9 level. So, resistant GBM cells can influence neighboring GBM cells by releasing miRNA-9 containing exosomes and conclusively cause GBM cells to acquire resistance to TMZ [70].

\section{Exosome as Glioma Biomarker}

Recently findings have revealed various exosomal markers such as gene [71], exosomal proteins [72], and exosomal miRNAs [72] as novel diagnostic biomarkers in glioma (Table 2). Glioma-derived exosomes enriched with various glioma-specific markers (IDH1 mutant, EGFR, EGFRvIII, and podoplanin (PDPN)) and hence could be applied as diagnostic biomarkers for glioma tumors [73, 74]. Recently Shao et al. reported a new and useful diagnostic approach based on an NMR-based chip assay for detecting and quantifying glioma exosome-related biomarkers such as IDH1, EGFR EGFRvIII, and PDPN of tumor bloodderived exosomes [75].

Exosomal molecular signatures such as MMPs, IL8, PDGFs, and CAV1 could use as a biomarker and new diagnostic tools to detect the oxygenation status and development of malignant tumors $[65,76]$.

Tumor-derived microvesicle analysis, RNA profile assay, determining levels of mRNAs and miRNAs provide new ways among molecular methods in detecting tumor formation, progression, and response to therapy [54, 77, 78].

miRNA is present inside a cell and the circulation [79]. These circulatory miRNA can be used as biomarkers in cancers [80]. For the first time, Valadi et al. suggest that exosomemediated miRNA transfer could be a route of genetic exchange between cells [81]. More 
studies proved that the functionality of miRNA is maintained during its transfer by exosomes [82].

Several exosomal miRNAs were identified in several cancer models, including breast, colon, prostate, pancreatic cancers, and glioblastoma [83-89].

Experiments have revealed that a subset of 11 miRNA abundant in gliomas was detected in microvesicles and donor cells of two different primary glioblastomas. Nucleic acids are good biomarkers because PCR detection is very sensitive. Skog et al. identify tumorspecific RNAs in serum exosomes [54].

High levels of miR-574-3p, miR-320, miR-10b, and miR-21 in GBM patient's blood could be suggested as a potent diagnostic biomarker in patients with brain tumors, especially miR-21, which is overexpressed in GBMs [90-92].

As the EGFRvIII mutant splice variant presents specifically in many glioblastomas, EGFR mRNA is the fascinating mRNA found in glioblastoma exosomes. [93]. It has been seen in approximately up to $60 \%$ of all high-grade gliomas [94]. It is detectable in tumor biopsies and serum microvesicles of glioblastoma patients. However, it is not detectable in serum samples of normal control. The sensitivity of this detection method can depend on tumor location, tumor size and serum volume, the amount of extracted RNA, cDNA conversion, and finally, PCR. This knowledge is important in therapeutic clinical trials [54].

Researchers found that exosomes from hypoxic conditions reflect hypoxic GBM cells' signals and patient tumors in another study. They also suggest that exosomal molecules can serve as a biomarker to assess GBM tumors' aggressiveness [65]. Other tumor-specific biomarkers revealed in brain tumors are isocitrate dehydrogenases 1 (IDH1) and 2 (IDH2) [9598].

Recent findings have demonstrated that glioblastoma and astrocyte cells release some of the microvesicles that carry mtDNA. Migration of mtDNA via exosomes and uptake by other cells can help understand some diseases caused by mitochondrial alterations [99-103].

Table 2. Various exosomal markers such as gene [71], exosomal proteins[72], and exosomal miRNAs [72] as novel diagnostic biomarkers in glioma.

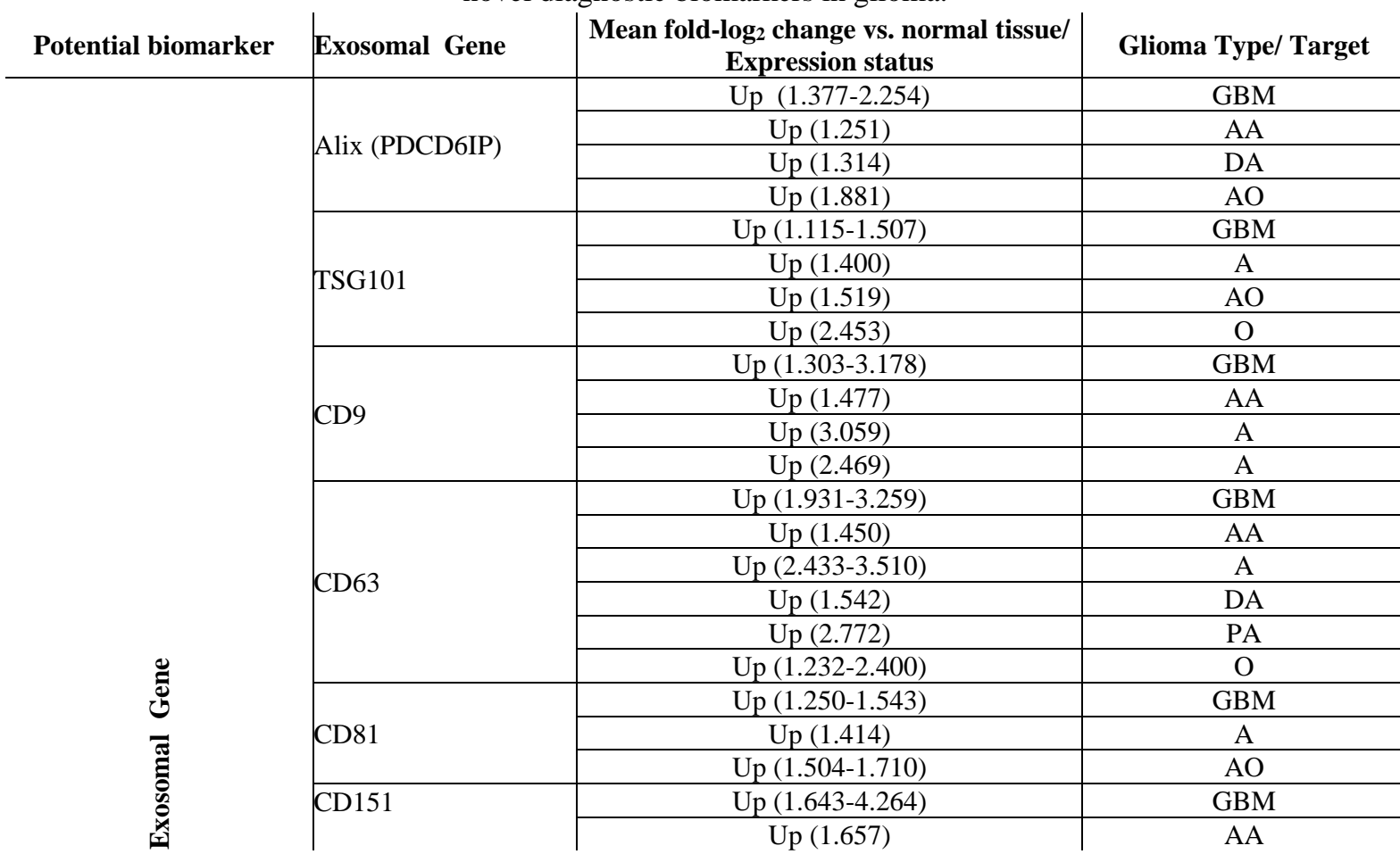




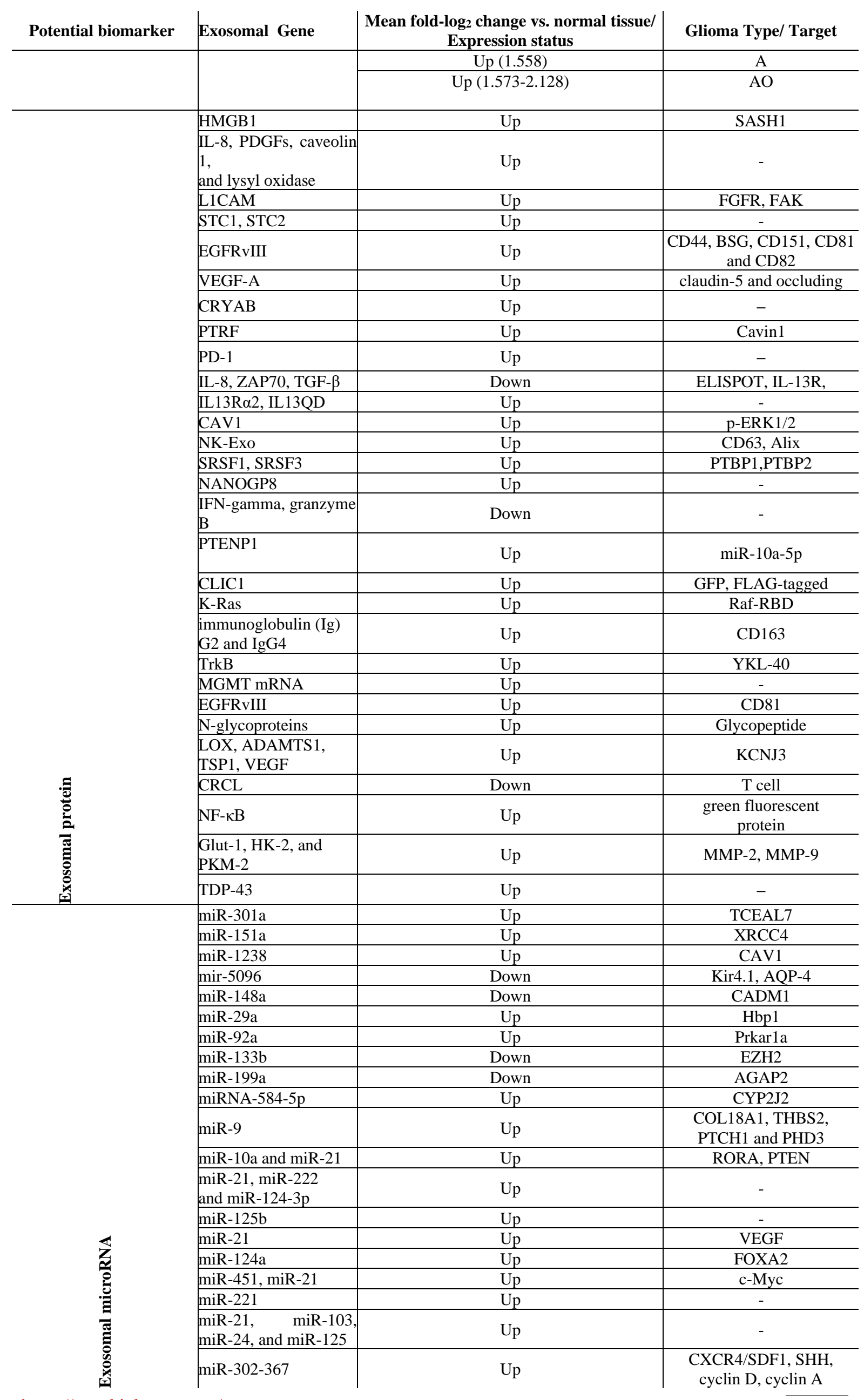




\begin{tabular}{|c|c|c|c|}
\hline Potential biomarker & Exosomal Gene & $\begin{array}{l}\text { Mean fold-log change vs. normal tissue/ } \\
\text { Expression status }\end{array}$ & Glioma Type/ Target \\
\hline & & & and E2F1 \\
\hline & miR-1290, miR-1246 & $\mathrm{Up}$ & - \\
\hline & miR-1587 & Down & NCOR1 \\
\hline & miR-375 & Down & SLC31A1 \\
\hline & miR-454-3p & Down & ATG12 \\
\hline & miR-146b & Down & EGFR and NF- $\kappa \mathrm{B}$ \\
\hline & miR-1246 & Down & TERF2IP \\
\hline & miR-124 & Down & CDK6 \\
\hline & $\begin{array}{l}\operatorname{miR}-328-3 p \\
\operatorname{miR}-339-5 p \\
\operatorname{miR}-340-5 p \\
\operatorname{miR}-485-3 p \text {, and } \operatorname{miR}- \\
543\end{array}$ & Up & - \\
\hline & $\begin{array}{l}\text { miR-182-5p, } \\
\text { miR-486-5p }\end{array}$ & Down & - \\
\hline & miR-301a & Up & PTEN \\
\hline & miR-221 & Up & DNM3 \\
\hline & miR-26a & $\mathrm{Up}$ & PTEN \\
\hline
\end{tabular}

\section{Exosome as a Nanocarrier}

Recent progress in nanomedicine [104-119] and biotechnology [116, 120-124] bring enormous potential in medicine and healthcare applications. Exosomes are considered endogenous nano delivery vehicles to overcome artificial vehicles' obstacles by their biocompatibility and biodegradability properties. Exosomes can evade detection by the immune system and have a long half-life in the circulation for therapeutic molecules such as proteins, mRNA, small interfering RNAs (siRNA), and contrast agents [125] (Figure 2).

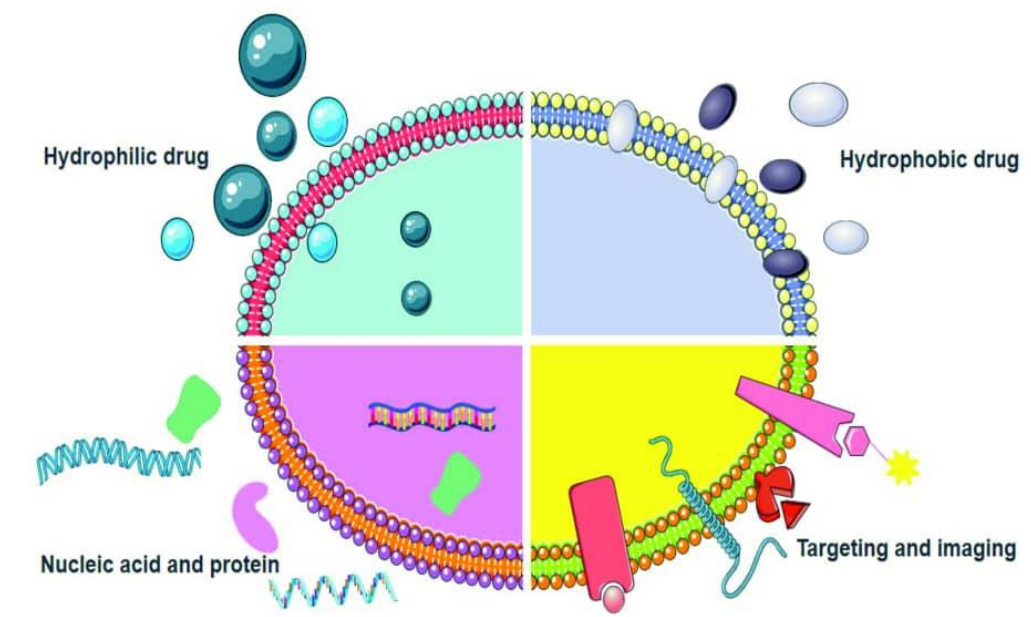

Figure 2. Schematic depicts the role of glioma-derived exosomes as a nanocarrier for various types of therapeutic agents such as nucleic acids (DNA, RNA), proteins, contrast agents. Hydrophilic and hydrophobic drugs. Targeting ligands can be attached to the surface of the exosome for therapeutic targeting.

The general property of cancer is microRNA deregulation. Exosomes could be used as a vehicle for the delivery of anti-tumor miRNAs. Especially miR-1 loss may critical step in GBM genesis and/or progression. miR-1 is a tumor suppressor in GBM. By reintroducing miR-1 can provide anti-proliferative, anti-angiogenic, and anti-invasive action for GBM. Because miR-1 simultaneously targets major components of oncogenic signaling networks (JNK, PRCs, MET, EGFR, ANXA2). Exosome-based microRNA reintroduction(especially miR-1 delivery) is a candidate for reducing GBM tumorigenicity. Exosome-derived miR-1 and ectopic expression of miR-1 is a unique example of miRNA-based therapy for GBM [90, $126,127]$. 
Exosomes released from brain tumor cells can escape the blood-brain barrier and potentially apply in malignant gliomas therapy. Recent findings suggest that exosomemediated delivery of therapeutic drugs is a new means for drug delivery, but more investigations and considerations are required to clarify the safety parameters, immunogenicity, as well as route of delivery across the BBB for future clinical application in CNS diseases [128-130].

Microglial cells have a substantial role in the progression of glioblastoma. Signal transducer and activator of transcription 3 (stat 3) have an important role in tumor growth, especially glioblastoma. So, Zhang et al. encapsulate stat 3 inhibitor JSI-124 in exosomes and deliver them through an intranasal pathway to mice bearing intracerebral tumors. They conclude that Exo-JSI-124 is taken up by microglial cells selectively and resulted in the enhancement of tumor apoptosis. They showed that this strategy is a non-invasive method to treat glioblastoma [131]. Munoz et al. used exosomes to transfer anti-miRNA to GBM cells with the therapeutic goal [70].

Brain-targeting exosomes were loaded with siRNAs by fusing neuron-targeting rabies viral glycoprotein (RVG) peptides in the N-terminus of Lamp2b, a murine exosomal membrane protein then brain-targeting Exosomes were delivered systematically into syngeneic mice, resulting in significant success in knock-down of the targeted mRNAs in the brain. This finding suggests brain-targeting Exosomes have promising potential in RNAi therapy [125, 129].

\section{Tumor-Derived Exosomes Roles in Glioma Vaccines Development}

At present, there is a clinical study that utilizes exosomes. (ClinicalTrial.gov website keywords search glioma + exosome): NCT01550523 is its clinical trial gov identifier. In this phase one pilot immunotherapy trial, scientists take the patient's tumor cells during surgical craniotomy and treat them to shut down a targeted surface receptor protein and then re-implant the cells, but this time in small diffusion chambers. Shutting down surface receptor protein causes the tumor cells to die through apoptosis. Now, dead cells release exosomes full of tumor antigens. These antigens can activate the immune system against the tumor. So, this product serves as a safe therapeutic vaccine.

Recent studies have approved that tumor-derived exosomes can use as anti-tumor vaccines, but there is a concern with the immunosuppressive properties of tumor exosomes $[94,132,133]$.

A vaccine against GBM is a promising method to eradicate this cancer. By triggering specific anti-tumor immune responses and immunotherapy, this GBM vaccine has reached ongoing phase III trials [7].

GBM exosomes were shown to be enriched by glioma antigens. Tumor exosomes that useful as antitumor-specific antigens immune vaccines based on autologous dendritic cells (DC). DC therapy is an appropriate immune therapeutic approach for the treatment and prevention of advanced cancer [134-138]. DC and exosome-based approaches seem promising approaches to effectively induce anti-tumor immune responses and increasing survival in glioma patients [137].

The recent finding has shown exosomes can be applied as a useful cancer vaccine vehicle in CNS diseases by using EGFRvIII peptides as GBM-specific antigens in combination with autologous DCs can serve as a means to administer active immunotherapy against GBM [125, 139-143]. 


\section{Concluding Remark}

Exosomes are recommended as new powerful tools for targeted anticancer drug delivery and exosome-based diagnostics in brain cancer. The exosome-based diagnostic is a non-invasive method without the need for surgery to obtain a tissue sample. Different exosomal molecular signatures have been used as a biomarker by detecting the oxygenation status and development of malignant tumors. Despite these, some technical challenges should be overcome before taking advantage of exosomes as biomarker or drug delivery carriers. For example, methods of exosome isolation are expensive and time-consuming. Likewise, their size distribution is wide, so they are not monodisperse as drug delivery carriers. Furthermore, they have diversity in their density and content, which will influence the investigation results. One of the challenges is understanding exosome signals in different brain cells because exosome signals are multifunctional and complex and can show antitumorigenic or protumorigenic effects depended on exosome content and recipient cells.

To use cancer-derived exosomes in treating glioma, analyses are needed to ensure they are free from angiogenic proteins that initiate angiogenesis and metastasis in glioma.

\section{Funding}

This work was supported by the International Campus, Tehran University of Medical Sciences (Grant no. 94-01-103-28528).

\section{Acknowledgments}

This research has no acknowledgment.

\section{Conflicts of Interest}

The authors declare no conflict of interest.

\section{References}

1. Huse, J.T.; Holland, E.; DeAngelis, L.M. Glioblastoma: molecular analysis and clinical implications. Annual review of medicine 2013, 64, 59-70, https://doi.org/10.1146/annurev-med-100711-143028.

2. Adamson, C.; Kanu, O.O.; Mehta, A.I.; Di, C.; Lin, N.; Mattox, A.K.; Bigner, D.D. Glioblastoma multiforme: a review of where we have been and where we are going. Expert Opinion on Investigational Drugs 2009, 18, 1061-1083, https://doi.org/10.1517/13543780903052764.

3. Kleihues, P.; Louis, D.N.; Scheithauer, B.W.; Rorke, L.B.; Reifenberger, G.; Burger, P.C.; Cavenee, W.K. The WHO classification of tumors of the nervous system. Journal of Neuropathology \& Experimental Neurology 2002, 61, 215-225, https://doi.org/10.1093/jnen/61.3.215.

4. Reardon, D.A.; Rich, J.N.; Friedman, H.S.; Bigner, D.D. Recent advances in the treatment of malignant astrocytoma. Journal of clinical oncology 2006, 24, 1253-1265, https://doi.org/10.1200/JCO.2005.04.5302.

5. Burger, P.C.; Vogel, F.S.; Green, S.B.; Strike, T.A. Glioblastoma multiforme and anaplastic astrocytoma pathologic criteria and prognostic implications. Cancer 1985, 56, 1106-1111, https://doi.org/10.1002/10970142(19850901)56:5<1106::AID-CNCR2820560525>3.0.CO;2-2.

6. Wen, P.Y.; Kesari, S. Malignant gliomas in adults. New England Journal of Medicine 2008, 359, 492-507, https://doi.org/10.1056/NEJMra0708126.

7. Xu, L.W.; Chow, K.K.; Lim, M.; Li, G. Current Vaccine Trials in Glioblastoma: A Review. Journal of immunology research 2014, 2014, https://doi.org/10.1155/2014/796856.

8. Wei, H.; Chen, Q.; Lin, L.; Sha, C.; Li, T.; Liu, Y.; Yin, X.; Xu, Y.; Chen, L.; Gao, W. Regulation of exosome production and cargo sorting. International Journal of Biological Sciences 2021, 17, https://doi.org/10.7150/ijbs.53671.

9. $\quad$ Lin, B.; Lei, Y.; Wang, J.; Zhu, L.; Wu, Y.; Zhang, H.; Wu, L.; Zhang, P.; Yang, C. Microfluidic-Based Exosome Analysis for Liquid Biopsy. Small Methods 2021, https://doi.org/10.1002/smtd.202001131. 
10. Xu, X.; Liu, Y.; Li, Y.; Chen, H.; Zhang, Y.; Liu, J.; Deng, S.; Zheng, Y.; Sun, X.; Wang, J. Selective exosome exclusion of miR-375 by glioma cells promotes glioma progression by activating the CTGF-EGFR pathway. Journal of Experimental \& Clinical Cancer Research 2021, 40, 1-20, https://doi.org/10.21203/rs.3.rs-66928/v2.

11. Nickel, W. Unconventional secretory routes: direct protein export across the plasma membrane of mammalian cells. Traffic 2005, 6, 607-614, https://doi.org/10.1111/j.1600-0854.2005.00302.x.

12. Prochiantz, A. Messenger proteins: homeoproteins, TAT and others. Current opinion in cell biology 2000, 12, 400-406, https://doi.org/10.1016/S0955-0674(00)00108-3.

13. Tetta, C.; Ghigo, E.; Silengo, L.; Deregibus, M.C.; Camussi, G. Extracellular vesicles as an emerging mechanism of cell-to-cell communication. Endocrine 2013, 44, 11-19, https://doi.org/10.1007/s12020-0129839-0.

14. Fang, Y.; Wu, N.; Gan, X.; Yan, W.; Morrell, J.C.; Gould, S.J. Higher-order oligomerization targets plasma membrane proteins and HIV gag to exosomes. PLoS biology 2007, 5, https://doi.org/10.1371/journal.pbio.0050158.

15. Poliakov, A.; Spilman, M.; Dokland, T.; Amling, C.L.; Mobley, J.A. Structural heterogeneity and protein composition of exosome-like vesicles (prostasomes) in human semen. The Prostate 2009, 69, 159-167, https://doi.org/10.1002/pros.20860.

16. Raiborg, C.; Rusten, T.E.; Stenmark, H. Protein sorting into multivesicular endosomes. Current opinion in cell biology 2003, 15, 446-455, https://doi.org/10.1016/S0955-0674(03)00080-2.

17. Mathivanan, S.; Ji, H.; Simpson, R.J. Exosomes: extracellular organelles important in intercellular communication. Journal of proteomics 2010, 73, 1907-1920, https://doi.org/10.1016/j.jprot.2010.06.006.

18. Åkerfelt, M.; Morimoto, R.I.; Sistonen, L. Heat shock factors: integrators of cell stress, development and lifespan. Nature reviews Molecular cell biology 2010, 11, 545-555, https://doi.org/10.1038/nrm2938.

19. Lv, L.-H.; Wan, Y.-L.; Lin, Y.; Zhang, W.; Yang, M.; Li, G.-L.; Lin, H.-M.; Shang, C.-Z.; Chen, Y.-J.; Min, J. Anticancer drugs cause release of exosomes with heat shock proteins from human hepatocellular carcinoma cells that elicit effective natural killer cell anti-tumor responses in vitro. Journal of Biological Chemistry 2012, 287, 15874-15885, https://doi.org/10.1074/jbc.m112.340588.

20. Cho, J.-a.; Lee, Y.-S.; Kim, S.-H.; Ko, J.-K.; Kim, C.-W. MHC independent anti-tumor immune responses induced by Hsp70-enriched exosomes generate tumor regression in murine models. Cancer letters 2009, 275, 256-265, https://doi.org/10.1016/j.canlet.2008.10.021.

21. Février, B.; Vilette, D.; Laude, H.; Raposo, G. Exosomes: a bubble ride for prions? Traffic 2005, 6, 10-17, https://doi.org/10.1111/j.1600-0854.2004.00247.x.

22. Bobrie, A.; Krumeich, S.; Reyal, F.; Recchi, C.; Moita, L.F.; Seabra, M.C.; Ostrowski, M.; Théry, C. Rab27a supports exosome-dependent and-independent mechanisms that modify the tumor microenvironment and can promote tumor progression. Cancer research 2012, 72, 4920-4930, https://doi.org/10.1158/00085472.can-12-0925.

23. Vidal, M.; Sainte-Marie, J.; Philippot, J.R.; Bienvenue, A. Asymmetric distribution of phospholipids in the membrane of vesicles released during in vitro maturation of guinea pig reticulocytes: evidence precluding a role for "aminophospholipid translocase". Journal of cellular physiology 1989, 140, 455-462, https://doi.org/10.1002/jcp.1041400308.

24. Beloribi, S.; Ristorcelli, E.; Breuzard, G.; Silvy, F.; Bertrand-Michel, J.; Beraud, E.; Verine, A.; Lombardo, D. Exosomal lipids impact notch signaling and induce death of human pancreatic tumoral SOJ-6 cells. PloS one 2012, 7, https://doi.org/10.1371/journal.pone.0047480.

25. Yuyama, K.; Sun, H.; Mitsutake, S.; Igarashi, Y. Sphingolipid-modulated exosome secretion promotes clearance of amyloid- $\beta$ by microglia. Journal of Biological Chemistry 2012, 287, 1097710989, https://dx.doi.org/10.1074\%2Fjbc.M111.324616.

26. Record, M.; Subra, C.; Silvente-Poirot, S.; Poirot, M. Exosomes as intercellular signalosomes and pharmacological effectors. Biochemical pharmacology 2011, 81, 1171-1182, https://doi.org/10.1016/j.bcp.2011.02.011.

27. Subra, C.; Grand, D.; Laulagnier, K.; Stella, A.; Lambeau, G.; Paillasse, M.; De Medina, P.; Monsarrat, B.; Perret, B.; Silvente-Poirot, S. Exosomes account for vesicle-mediated transcellular transport of activatable phospholipases and prostaglandins. Journal of lipid research 2010, 51, 2105-2120, https://doi.org/10.1194/jlr.M003657.

28. Xie, Y.; Dang, W.; Zhang, S.; Yue, W.; Yang, L.; Zhai, X.; Yan, Q.; Lu, J. The role of exosomal non-coding RNAs in cancer. Molecular cancer 2019, 18, 1-10, https://doi.org/10.1186/s12943-019-0984-4.

29. Sun, Z.; Yang, S.; Zhou, Q.; Wang, G.; Song, J.; Li, Z.; Zhang, Z.; Xu, J.; Xia, K.; Chang, Y. Emerging role of exosome-derived long non-coding RNAs in tumor microenvironment. Molecular cancer 2018, 17, 1-9, https://doi.org/10.1186/s12943-018-0831-Z.

30. Lee, Y.R.; Kim, G.; Tak, W.Y.; Jang, S.Y.; Kweon, Y.O.; Park, J.G.; Lee, H.W.; Han, Y.S.; Chun, J.M.; Park, S.Y. Circulating exosomal non-coding RNAs as prognostic biomarkers in human hepatocellular carcinoma. International journal of cancer 2019, 144, 1444-1452, https://doi.org/10.1002/ijc.31931.

31. Da, M.; Jiang, H.; Xie, Y.; Jin, W.; Han, S. The Biological Roles of Exosomal Long Non-Coding RNAs in Cancers. OncoTargets and Therapy 2021, 14, 271-287, https://doi.org/10.2147/OTT.S281175. 
32. Li, S.; Zhang, M.; Zhang, H.; Hu, K.; Cai, C.; Wang, J.; Shi, L.; Ma, P.; Xu, Y.; Zheng, P. Exosomal long non-coding RNA lnc-GNAQ-6: 1 may serve as a diagnostic marker for gastric cancer. Clinica Chimica Acta 2020, 501, 252-257, https://doi.org/10.1016/j.cca.2019.10.047.

33. Mu, H.; Zhang, S.; Yao, Z.; Liu, Y.; Lin, K.; Zhao, Z.; Zhu, Y. The diagnostic and prognostic value of exosome-derived long non-coding RNAs in cancer patients: A meta-analysis. Clinical and Experimental Medicine 2020, 20, 339-348, https://doi.org/10.1007/s10238-020-00638-Z.

34. Cheng, J.; Meng, J.; Zhu, L.; Peng, Y. Exosomal non-coding RNAs in Glioma: biological functions and potential clinical applications. Molecular cancer 2020, 19, 1-14, https://doi.org/10.1186/s12943-020-011893.

35. Regehr, W.G.; Carey, M.R.; Best, A.R. Activity-dependent regulation of synapses by retrograde messengers. Neuron 2009, 63, 154-170, https://doi.org/10.1016/j.neuron.2009.06.021.

36. Chivet, M.; Hemming, F.; Pernet-Gallay, K.; Fraboulet, S.; Sadoul, R. Emerging role of neuronal exosomes in the central nervous system. Frontiers in physiology 2012, 3, https://doi.org/10.3389/fphys.2012.00145.

37. Aguzzi, A.; Rajendran, L. The transcellular spread of cytosolic amyloids, prions, and prionoids. Neuron 2009, 64, 783-790, https://doi.org/10.1016/j.neuron.2009.12.016.

38. Rajendran, L.; Honsho, M.; Zahn, T.R.; Keller, P.; Geiger, K.D.; Verkade, P.; Simons, K. Alzheimer's disease $\beta$-amyloid peptides are released in association with exosomes. Proceedings of the National Academy of Sciences 2006, 103, 11172-11177, https://doi.org/10.1073/pnas.0603838103.

39. Qian, M.; Chen, Z.; Guo, X.; Wang, S.; Zhang, Z.; Qiu, W.; Qi, Y.; Zhang, S.; Xu, J.; Zhao, R. Exosomes derived from hypoxic glioma deliver miR-1246 and miR-10b-5p to normoxic glioma cells to promote migration and invasion. Laboratory Investigation 2021, 1-13, https://doi.org/10.1038/s41374-020-00522-0.

40. Yin, J.; Ge, X.; Shi, Z.; Yu, C.; Lu, C.; Wei, Y.; Zeng, A.; Wang, X.; Yan, W.; Zhang, J. Extracellular vesicles derived from hypoxic glioma stem-like cells confer temozolomide resistance on glioblastoma by delivering miR-30b-3p. Theranostics 2021, 11, https://doi.org/10.7150/thno.47057.

41. Sharma, K.D.; Schaal, D.; Kore, R.A.; Hamzah, R.N.; Pandanaboina, S.C.; Hayar, A.; Griffin, R.J.; Srivatsan, M.; Reyna, N.S.; Xie, J.Y. Glioma-derived exosomes drive the differentiation of neural stem cells to astrocytes. Plos one 2020, 15, https://dx.doi.org/10.1371\%2Fjournal.pone.0234614.

42. Li, Z.; Ye, L.; Wang, L.; Quan, R.; Zhou, Y.; Li, X. Identification of miRNA signatures in serum exosomes as a potential biomarker after radiotherapy treatment in glioma patients. Annals of diagnostic pathology 2020, 44, https://doi.org/10.1016/j.anndiagpath.2019.151436.

43. Fauré, J.; Lachenal, G.; Court, M.; Hirrlinger, J.; Chatellard-Causse, C.; Blot, B.; Grange, J.; Schoehn, G.; Goldberg, Y.; Boyer, V. Exosomes are released by cultured cortical neurones. Molecular and Cellular Neuroscience 2006, 31, 642-648, https://doi.org/10.1016/j.mcn.2005.12.003.

44. Thayanithy, V.; Babatunde, V.; Dickson, E.L.; Wong, P.; Oh, S.; Ke, X.; Barlas, A.; Fujisawa, S.; Romin, Y.; Moreira, A.L. Tumor exosomes induce tunneling nanotubes in lipid raft-enriched regions of human mesothelioma cells. Experimental cell research 2014, 323, 178-188, https://doi.org/10.1016/j.yexcr.2014.01.014.

45. Christianson, H.C.; Svensson, K.J.; van Kuppevelt, T.H.; Li, J.-P.; Belting, M. Cancer cell exosomes depend on cell-surface heparan sulfate proteoglycans for their internalization and functional activity. Proceedings of the National Academy of Sciences 2013, 110, 17380-17385, https://doi.org/10.1073/pnas.1304266110.

46. Wade, A.; Robinson, A.E.; Engler, J.R.; Petritsch, C.; James, C.D.; Phillips, J.J. Proteoglycans and their roles in brain cancer. FEBS Journal 2013, 280, 2399-2417, https://doi.org/10.1111/febs.12109.

47. Mazzocca, A.; Coppari, R.; De Franco, R.; Cho, J.-Y.; Libermann, T.A.; Pinzani, M.; Toker, A. A secreted form of ADAM9 promotes carcinoma invasion through tumor-stromal interactions. Cancer research 2005, 65, 4728-4738, https://doi.org/10.1158/0008-5472.can-04-4449.

48. Müerköster, S.; Wegehenkel, K.; Arlt, A.; Witt, M.; Sipos, B.; Kruse, M.-L.; Sebens, T.; Klöppel, G.; Kalthoff, H.; Fölsch, U.R. Tumor stroma interactions induce chemoresistance in pancreatic ductal carcinoma cells involving increased secretion and paracrine effects of nitric oxide and interleukin-1 $\beta$. Cancer research 2004, 64, 1331-1337, https://doi.org/10.1158/0008-5472.can-03-1860.

49. Singer, C.F.; Gschwantler-Kaulich, D.; Fink-Retter, A.; Haas, C.; Hudelist, G.; Czerwenka, K.; Kubista, E. Differential gene expression profile in breast cancer-derived stromal fibroblasts. Breast cancer research and treatment 2008, 110, 273-281, https://doi.org/10.1007/s10549-007-9725-2.

50. Kaplan, R.N.; Riba, R.D.; Zacharoulis, S.; Bramley, A.H.; Vincent, L.; Costa, C.; MacDonald, D.D.; Jin, D.K.; Shido, K.; Kerns, S.A. VEGFR1-positive haematopoietic bone marrow progenitors initiate the premetastatic niche. Nature 2005, 438, 820-827, https://doi.org/10.1038/nature04186.

51. Castellana, D.; Zobairi, F.; Martinez, M.C.; Panaro, M.A.; Mitolo, V.; Freyssinet, J.-M.; Kunzelmann, C. Membrane microvesicles as actors in the establishment of a favorable prostatic tumoral niche: a role for activated fibroblasts and CX3CL1-CX3CR1 axis. Cancer research 2009, 69, 785-793, https://doi.org/10.1158/0008-5472.CAN-08-1946.

52. Gabrilovich, D.I. Editorial [Hot Topic: Molecular Mechanisms and Therapeutic Reversal of Immune Suppression in Cancer (Guest Editor: Dmitry I. Gabrilovich)]. Current cancer drug targets 2007, 7, 1-1, https://doi.org/10.2174/1568009610707010001. 
53. Ratajczak, J.; Wysoczynski, M.; Hayek, F.; Janowska-Wieczorek, A.; Ratajczak, M. Membrane-derived microvesicles: important and underappreciated mediators of cell-to-cell communication. Leukemia 2006, 20, 1487-1495, https://doi.org/10.1038/sj.leu.2404296.

54. Skog, J.; Würdinger, T.; van Rijn, S.; Meijer, D.H.; Gainche, L.; Curry, W.T.; Carter, B.S.; Krichevsky, A.M.; Breakefield, X.O. Glioblastoma microvesicles transport RNA and proteins that promote tumour growth and provide diagnostic biomarkers. Nature cell biology 2008, 10, 1470-1476, https://doi.org/10.1038/ncb1800.

55. Smalheiser, N.R. Exosomal transfer of proteins and RNAs at synapses in the nervous system. Biol Direct 2007, 2, 1-15, https://doi.org/10.1186/1745-6150-2-35.

56. Azmi, A.S.; Bao, B.; Sarkar, F.H. Exosomes in cancer development, metastasis, and drug resistance: a comprehensive review. Cancer and Metastasis Reviews 2013, 32, 623-642, https://doi.org/10.1007/s10555013-9441-9.

57. Svensson, K.J.; Belting, M. Role of extracellular membrane vesicles in intercellular communication of the tumour microenvironment. Biochemical Society Transactions 2013, 41, 273-276, https://doi.org/10.1042/BST20120248.

58. Grange, C.; Tapparo, M.; Collino, F.; Vitillo, L.; Damasco, C.; Deregibus, M.C.; Tetta, C.; Bussolati, B.; Camussi, G. Microvesicles released from human renal cancer stem cells stimulate angiogenesis and formation of lung premetastatic niche. Cancer research 2011, 71, 5346-5356, https://doi.org/10.1158/00085472.can-11-0241.

59. King, H.W.; Michael, M.Z.; Gleadle, J.M. Hypoxic enhancement of exosome release by breast cancer cells. BMC cancer 2012, 12, https://doi.org/10.1186/1471-2407-12-421.

60. Panigrahi, G.K.; Praharaj, P.P.; Peak, T.C.; Long, J.; Singh, R.; Rhim, J.S.; Abd Elmageed, Z.Y.; Deep, G. Hypoxia-induced exosome secretion promotes survival of African-American and Caucasian prostate cancer cells. Scientific reports 2018, 8, 1-13, https://doi.org/10.1038/s41598-018-22068-4.

61. Kumar, A.; Deep, G. Hypoxia in tumor microenvironment regulates exosome biogenesis: molecular mechanisms and translational opportunities. Cancer letters 2020, 479, 23-30, https://doi.org/10.1016/j.canlet.2020.03.017.

62. Kumar, A.; Deep, G. Exosomes in hypoxia-induced remodeling of the tumor microenvironment. Cancer Letters 2020, 488, 1-8, https://doi.org/10.1016/j.canlet.2020.05.018.

63. Deep, G.; Jain, A.; Kumar, A.; Agarwal, C.; Kim, S.; Leevy, W.M.; Agarwal, R. Exosomes secreted by prostate cancer cells under hypoxia promote matrix metalloproteinases activity at pre-metastatic niches. Molecular carcinogenesis 2020, 59, 323-332, https://doi.org/10.1002/mc.23157.

64. Li, J.; Yuan, H.; Xu, H.; Zhao, H.; Xiong, N. Hypoxic cancer-secreted exosomal miR-182-5p promotes glioblastoma angiogenesis by targeting Kruppel-like factor 2 and 4. Molecular Cancer Research 2020, 18, 1218-1231, https://doi.org/10.1158/1541-7786.MCR-19-0725.

65. Kucharzewska, P.; Christianson, H.C.; Welch, J.E.; Svensson, K.J.; Fredlund, E.; Ringnér, M.; Mörgelin, M.; Bourseau-Guilmain, E.; Bengzon, J.; Belting, M. Exosomes reflect the hypoxic status of glioma cells and mediate hypoxia-dependent activation of vascular cells during tumor development. Proceedings of the National Academy of Sciences 2013, 110, 7312-7317, https://doi.org/10.1073/pnas.1220998110.

66. Park, J.E.; Tan, H.S.; Datta, A.; Lai, R.C.; Zhang, H.; Meng, W.; Lim, S.K.; Sze, S.K. Hypoxic tumor cell modulates its microenvironment to enhance angiogenic and metastatic potential by secretion of proteins and exosomes. Molecular \& Cellular Proteomics 2010, 9, 1085-1099, https://doi.org/10.1074/mcp.m900381mcp200.

67. Svensson, K.J.; Kucharzewska, P.; Christianson, H.C.; Sköld, S.; Löfstedt, T.; Johansson, M.C.; Mörgelin, M.; Bengzon, J.; Ruf, W.; Belting, M. Hypoxia triggers a proangiogenic pathway involving cancer cell microvesicles and PAR-2-mediated heparin-binding EGF signaling in endothelial cells. Proceedings of the National Academy of Sciences 2011, 108, 13147-13152, https://doi.org/10.1073/pnas.1104261108.

68. Meads, M.B.; Gatenby, R.A.; Dalton, W.S. Environment-mediated drug resistance: a major contributor to minimal residual disease. Nature Reviews Cancer 2009, 9, 665-674, https://doi.org/10.1038/nrc2714.

69. Pilzer, D.; Fishelson, Z. Mortalin/GRP75 promotes release of membrane vesicles from immune attacked cells and protection from complement-mediated lysis. International immunology 2005, 17, 1239-1248, https://doi.org/10.1093/intimm/dxh300.

70. Munoz, J.L.; Bliss, S.A.; Greco, S.J.; Ramkissoon, S.H.; Ligon, K.L.; Rameshwar, P. Delivery of Functional Anti-miR-9 by Mesenchymal Stem Cell-derived Exosomes to Glioblastoma Multiforme Cells Conferred Chemosensitivity. Molecular Therapy—Nucleic Acids 2013, 2, https://doi.org/10.1038/mtna.2013.60.

71. Gourlay, J.; Morokoff, A.; Luwor, R.; Zhu, H.-J.; Kaye, A.; Stylli, S. The emergent role of exosomes in glioma. Journal of Clinical Neuroscience 2017, 35, 13-23, https://doi.org/10.1016/j.jocn.2016.09.021.

72. Ghaemmaghami, A.B.; Mahjoubin-Tehran, M.; Movahedpour, A.; Morshedi, K.; Sheida, A.; Taghavi, S.P.; Mirzaei, H.; Hamblin, M.R. Role of exosomes in malignant glioma: microRNAs and proteins in pathogenesis and diagnosis. Cell Communication and Signaling 2020, 18, 1-19, https://doi.org/10.1186/s12964-02000623-9. 
73. Redzic, J.S.; Ung, T.H.; Graner, M.W. Glioblastoma extracellular vesicles: reservoirs of potential biomarkers. Pharmacogenomics and personalized medicine 2014, 7, 65-77, https://doi.org/10.2147/pgpm.s39768.

74. Naryzhny, S.; Volnitskiy, A.; Kopylov, A.; Zorina, E.; Kamyshinsky, R.; Bairamukov, V.; Garaeva, L.; Shlikht, A.; Shtam, T. Proteome of glioblastoma-derived exosomes as a source of biomarkers. Biomedicines 2020, 8, https://doi.org/10.3390/biomedicines8070216.

75. Shao, H.; Chung, J.; Balaj, L.; Charest, A.; Bigner, D.D.; Carter, B.S.; Hochberg, F.H.; Breakefield, X.O.; Weissleder, R.; Lee, H. Protein typing of circulating microvesicles allows real-time monitoring of glioblastoma therapy. Nature medicine 2012, 18, 1835-1840, https://doi.org/10.1038/nm.2994.

76. Harris, A.L. Hypoxia — a key regulatory factor in tumour growth. Nature Reviews Cancer 2002, 2, 38-47, https://doi.org/10.1038/nrc704.

77. Sonabend, A.M.; Dana, K.; Lesniak, M.S. Targeting epidermal growth factor receptor variant III: a novel strategy for the therapy of malignant glioma. 2007, https://doi.org/10.1586/14737140.7.12s.S45.

78. Mellinghoff, I.K.; Wang, M.Y.; Vivanco, I.; Haas-Kogan, D.A.; Zhu, S.; Dia, E.Q.; Lu, K.V.; Yoshimoto, K.; Huang, J.H.; Chute, D.J. Molecular determinants of the response of glioblastomas to EGFR kinase inhibitors. New England Journal of Medicine 2005, 353, 2012-2024, https://doi.org/10.1056/NEJMoa051918.

79. Mitchell, P.S.; Parkin, R.K.; Kroh, E.M.; Fritz, B.R.; Wyman, S.K.; Pogosova-Agadjanyan, E.L.; Peterson, A.; Noteboom, J.; O'Briant, K.C.; Allen, A. Circulating microRNAs as stable blood-based markers for cancer detection. Proceedings of the National Academy of Sciences 2008, 105, 10513-10518, https://doi.org/10.1073/pnas.0804549105.

80. Cortez, M.A.; Bueso-Ramos, C.; Ferdin, J.; Lopez-Berestein, G.; Sood, A.K.; Calin, G.A. MicroRNAs in body fluids - the mix of hormones and biomarkers. Nature reviews Clinical oncology 2011, 8, 467-477, https://doi.org/10.1038/nrclinonc.2011.76.

81. Valadi, H.; Ekström, K.; Bossios, A.; Sjöstrand, M.; Lee, J.J.; Lötvall, J.O. Exosome-mediated transfer of mRNAs and microRNAs is a novel mechanism of genetic exchange between cells. Nature cell biology 2007, 9, 654-659, https://doi.org/10.1038/ncb1596.

82. Koga, Y.; Yasunaga, M.; Moriya, Y.; Akasu, T.; Fujita, S.; Yamamoto, S.; Matsumura, Y. Exosome can prevent RNase from degrading microRNA in feces. Journal of gastrointestinal oncology 2011, 2, https://doi.org/10.3978/j.issn.2078-6891.2011.015.

83. Eichelser, C.; Stuckrath, I.; Muller, V.; Milde-Langosch, K.; Wikman, H.; Pantel, K.; Schwarzenbach, H. Increased serum levels of circulating exosomal microRNA-373 in receptor-negative breast cancer patients. Oncotarget 2014, 5, 9650-9663, https://doi.org/10.18632/oncotarget.2520.

84. Hannafon, B.N.; Trigoso, Y.D.; Calloway, C.L.; Zhao, Y.D.; Lum, D.H.; Welm, A.L.; Zhao, Z.J.; Blick, K.E.; Dooley, W.C.; Ding, W. Plasma exosome microRNAs are indicative of breast cancer. Breast Cancer Research 2016, 18, https://doi.org/10.1186/s13058-016-0753-X.

85. Liu, C.; Eng, C.; Shen, J.; Lu, Y.; Takata, Y.; Mehdizadeh, A.; Chang, G.J.; Rodriguez-Bigas, M.A.; Li, Y.; Chang, P. Serum exosomal miR-4772-3p is a predictor of tumor recurrence in stage II and III colon cancer. Oncotarget 2016, 7, 76250-76260, https://doi.org/10.18632/oncotarget.12841.

86. Ogata-Kawata, H.; Izumiya, M.; Kurioka, D.; Honma, Y.; Yamada, Y.; Furuta, K.; Gunji, T.; Ohta, H.; Okamoto, H.; Sonoda, H. Circulating exosomal microRNAs as biomarkers of colon cancer. PloS one 2014, 9, https://doi.org/10.1371/journal.pone.0092921.

87. Bryant, R.; Pawlowski, T.; Catto, J.; Marsden, G.; Vessella, R.; Rhees, B.; Kuslich, C.; Visakorpi, T.; Hamdy, F. Changes in circulating microRNA levels associated with prostate cancer. British journal of cancer 2012, 106, 768-774, https://doi.org/10.1038/bjc.2011.595.

88. Que, R.; Ding, G.; Chen, J.; Cao, L. Analysis of serum exosomal microRNAs and clinicopathologic features of patients with pancreatic adenocarcinoma. World journal of surgical oncology 2013, 11, https://doi.org/10.1186/1477-7819-11-219.

89. Manterola, L.; Guruceaga, E.; Pérez-Larraya, J.G.; González-Huarriz, M.; Jauregui, P.; Tejada, S.; DiezValle, R.; Segura, V.; Samprón, N.; Barrena, C. A small noncoding RNA signature found in exosomes of GBM patient serum as a diagnostic tool. Neuro-oncology 2014, 16, 520-527, https://doi.org/10.1093/neuonc/not218.

90. Bronisz, A.; Wang, Y.; Nowicki, M.O. Extracellular vesicles modulate the glioblastoma. Cancer research 2014, 738-750, https://doi.org/10.1158/0008-5472.CAN-13-2650.

91. Bronisz, A.M.; Godlewski, J.; Wallace, J.; Merchant, A.; Leone, G.; Ostrowski, M.C. Reprogramming of the tumor microenvironment by stromal Pten-regulated miR-320. Cancer research 2011, 14, 159-167, https://doi.org/10.1038/ncb2396.

92. Koshkin, P.A.; Chistiakov, D.A.; Nikitin, A.G.; Konovalov, A.N.; Potapov, A.A.; Usachev, D.Y.; Pitskhelauri, D.I.; Kobyakov, G.L.; Shishkina, L.V.; Chekhonin, V.P. Analysis of expression of microRNAs and genes involved in the control of key signaling mechanisms that support or inhibit development of brain tumors of different grades. Clinica Chimica Acta 2014, 430, 55-62, https://doi.org/10.1016/j.cca.2014.01.001. 
93. Nishikawa, R.; Sugiyama, T.; Narita, Y.; Furnari, F.; Cavenee, W.K.; Matsutani, M. Immunohistochemical analysis of the mutant epidermal growth factor, $\triangle \mathrm{EGFR}$, in glioblastoma. Brain tumor pathology 2004, 21, 53-56, https://doi.org/10.1007/BF02484510.

94. Graner, M.W.; Alzate, O.; Dechkovskaia, A.M.; Keene, J.D.; Sampson, J.H.; Mitchell, D.A.; Bigner, D.D. Proteomic and immunologic analyses of brain tumor exosomes. The FASEB Journal 2009, 23, 1541-1557, https://doi.org/10.1096/fj.08-122184.

95. Dang, L.; White, D.W.; Gross, S.; Bennett, B.D.; Bittinger, M.A.; Driggers, E.M.; Fantin, V.R.; Jang, H.G.; Jin, S.; Keenan, M.C. Cancer-associated IDH1 mutations produce 2-hydroxyglutarate. Nature 2009, 462, 739-744, https://doi.org/10.1038/nature08617.

96. Duncan, C.G.; Barwick, B.G.; Jin, G.; Rago, C.; Kapoor-Vazirani, P.; Powell, D.R.; Chi, J.-T.; Bigner, D.D.; Vertino, P.M.; Yan, H. A heterozygous IDH1R132H/WT mutation induces genome-wide alterations in DNA methylation. Genome research 2012, 22, 2339-2355, https://doi.org/10.1101/gr.132738.111.

97. Ichimura, K. Molecular pathogenesis of IDH mutations in gliomas. Brain tumor pathology 2012, 29, 131139, https://doi.org/10.1007/s10014-012-0090-4.

98. Chen, W.W.; Balaj, L.; Liau, L.M.; Samuels, M.L.; Kotsopoulos, S.K.; Maguire, C.A.; LoGuidice, L.; Soto, H.; Garrett, M.; Zhu, L.D. BEAMing and droplet digital PCR analysis of mutant IDH1 mRNA in glioma patient serum and cerebrospinal fluid extracellular vesicles. Molecular Therapy-Nucleic Acids 2013, 2, https://doi.org/10.1038/mtna.2013.28.

99. Guescini, M.; Genedani, S.; Stocchi, V.; Agnati, L.F. Astrocytes and Glioblastoma cells release exosomes carrying mtDNA. Journal of neural transmission 2010, 117, 1-4, https://doi.org/10.1007/s00702-009-02888.

100. Mears, R.; Craven, R.A.; Hanrahan, S.; Totty, N.; Upton, C.; Young, S.L.; Patel, P.; Selby, P.J.; Banks, R.E. Proteomic analysis of melanoma-derived exosomes by two-dimensional polyacrylamide gel electrophoresis and mass spectrometry. Proteomics 2004, 4, 4019-4031, https://doi.org/10.1002/pmic.200400876.

101. Staubach, S.; Razawi, H.; Hanisch, F.G. Proteomics of MUC1-containing lipid rafts from plasma membranes and exosomes of human breast carcinoma cells MCF-7. Proteomics 2009, 9, 2820-2835, https://doi.org/10.1002/pmic.200800793.

102. Schapira, A.H. Mitochondrial disease. The Lancet 2006, 368, 70-82, https://doi.org/10.1016/S01406736(06)68970-8.

103. Agnati, L.; Guidolin, D.; Baluska, F.; Barlow, P.; Carone, C.; Genedani, S. A new hypothesis of pathogenesis based on the divorce between mitochondria and their host cells: possible relevance for Alzheimer's disease. Current Alzheimer Research 2010, 7, 307-322, https://doi.org/10.2174/156720510791162395.

104. Rasouli, R.; Barhoum, A.; Uludag, H. A review of nanostructured surfaces and materials for dental implants: surface coating, patterning and functionalization for improved performance. Biomaterials science 2018, 6 , 1312-1338, https://doi.org/10.1039/c8bm00021b.

105. Rasouli, R.; Barhoum, A.; Bechelany, M.; Dufresne, A. Nanofibers for biomedical and healthcare applications. Macromolecular bioscience 2019, 19, https://doi.org/10.1002/mabi.201800256

106. Akbarian, S.; Sojoodi, J.; Monnavari, F.; Heidari, H.; Khosravian, P.; A Javar, H.; Assadi, A.; Rasouli, R.; Saffari, M.; Shandiz, A.S.S. Nano conjugated PLGA-Chlorambucil: Synthesis In vitro anti non-Hodgkin's lymphoma cellular assay. Letters in Drug Design \& Discovery 2017, 14, 827-836, https://doi.org/10.2174/1570180814666161130113446.

107. Hashempour Alamdari, N.; Alaei-Beirami, M.; Sadat Shandiz, S.A.; Hejazinia, H.; Rasouli, R.; Saffari, M.; Sadat Ebrahimi, S.E.; Assadi, A.; Shafiee Ardestani, M. Gd3+-asparagine-anionic linear globular dendrimer second-generation G2 complexes: novel nanobiohybrid theranostics. Contrast media \& molecular imaging 2017, 2017, https://doi.org/10.1155/2017/3625729.

108. Nazeri, N.; Karimi, R.; Ghanbari, H. The effect of surface modification of poly-lactide-co-glycolide/carbon nanotube nanofibrous scaffolds by laminin protein on nerve tissue engineering. Journal of Biomedical Materials Research Part A 2021, 109, 159-169, https://doi.org/10.1002/jbm.a.37013.

109. Nazeri, N.; Derakhshan, M.A.; Faridi-Majidi, R.; Hossein Ghanbari. Novel electro-conductive nanocomposites based on electrospun PLGA/CNT for biomedical applications. Journal of Materials Science: Materials in Medicine 2018, 29, 1-9, https://doi.org/10.1007/s10856-018-6176-8

110. Rasouli, R.; Barhoum, A. Advances in nanofibers for antimicrobial drug delivery. Handbook of Nanofibers 2018, 1-42, https://doi.org/10.1007/978-3-319-42789-8_33-1.

111. Kebriaezadeh, A.; Ashrafi, S.; Rasouli, R.; Ebrahimi, S.E.S.; Hamedani, M.P.; Assadi, A.; Saffari, M.; Ardestani, M.S. Gadobutrol-dendrimer effects on metastatic and apoptotic gene expression. Advances in nano research 2016, 4, http://dx.doi.org/10.12989/anr.2016.4.2.145.

112. Hosseinian, Z.; Rasouli, R.; Azarnoosh, A.; Mortazavi, M.; Akbarzadeh, A. Evaluation of magnetic nanoparticles loaded with cisplatin Performance on breast cancer in In vivo and in vitro studies. New Cellular and Molecular Biotechnology Journal 2015, 5, 29-36.

113. Ebrahimi, S.H.; Rasouli, R.; Alavi, S.E.; Akbarzadeh, A.; Koohi, M.E.M. Investigation of effective factors in preparation of polybutyl cyanoacrylate nanoparticles by emulsion polymerization. New Cellular and Molecular Biotechnology Journal 2015, 5, 33-38. 
114. Nazeri, N.; Tajerian, R.; Arabpour, Z.; Hadjighassem, M.R.; Gheibi, N.; Manouchehrabadi, M.; Ghanbari, H. Bioinspired immobilization of carbon nanotubes on scaffolds for nerve regeneration. Bioinspired, Biomimetic and Nanobiomaterials 2019, 8, 198-205, https://doi.org/10.33263/BRIAC114.1124411255.

115. Ebrahim Shahmabadi, H.; Rasouli, R.; Alavi, S.E.; Koohi Moftakhari Esfahani, M. Investigation of effective factors in preparation of polybutyl cyanoacrylate nanoparticles by emulsion polymerization. New Cellular and Molecular Biotechnology Journal 2015, 5, 32-38.

116. Rasouli, R.; Alaei-Beirami, M.; Zaaeri, F. Nanobased Cns Delivery Systems. In: Nanobiomaterials. Apple Academic Press: 2018; pp. 441-473.

117. Keshavarz, A.; Hajbabaei, S.; Sojoodi, J.; Mostafa, S.; Afshar, M. Mn2+ negatively charged pegylated dendrimer G2-tryptophan: Novel nano magnetic resonance imaging agent. Adv Appl Physiol 2017, 2, 1-9, https://doi.org/10.11648/j.aap.20170201.11.

118. Rasouli, R.; Alikhani, Z.; Shafiee, A.M.; Faridi, M.R.; Ebrahimi, S.F. Nanotechnology in the development of vaccines. Acecr Scientific Information Database 2015, 16.

119. Barhoum, A.; Rasouli, R.; Zadeh, M.Y.; Bechelany, M. Nanofibers Technology: History and Developments. Springer International: 2018; pp. 1-42, https://doi.org/10.1007/978-3-319-42789-8_54-1.

120. Shafaghi, M.; Maktoobian, S.; Rasouli, R.; Howaizi, N.; Ofoghi, H.; Ehsani, P. Transient expression of biologically active anti-rabies virus monoclonal antibody in tobacco leaves. Iranian journal of biotechnology 2018, 16, https://doi.org/10.21859/IJB.1774.

121. Rasouli, R.; Honari, H.; Alizadeh, H.; Gorjian, M.; Jalali, M.; Aalayi, M. Expression of protective antigen of bacillus anthracis in Iranian variety of lettuce plastid (Lactuca sativa L.). Middle-East J. Sci. Res 2014, 21, 1855-1861.

122. Bay, H.; Rasouli, R.; Jafari, A.; Ehsani, P. Expression of IpaD of Shigella flexneri in Tobacco plant and Escherichia coli, which one is the better choice? Research in Pharmaceutical Sciences 2012, 7, 505.

123. Maktobian, S.; Ehsani, P.; Rasouli, R.; Ofoghi, H. Transient expression of anti-rabies-light chain antibody in Tobacco plants. Research in Pharmaceutical Sciences 2012, 7.

124. Ohadi, M.; Rasouli, R.; Jafari, A.; Ehsani, P. Transient expression of IpaB of Shigella flexneri in Nicotiana tabaccum in comparison to expressed protein in Escherichia coli. Research in Pharmaceutical Sciences $\mathbf{2 0 1 2}, 7$.

125. Lai, C.P.-K.; Breakefield, X.O. Role of exosomes/microvesicles in the nervous system and use in emerging therapies. Frontiers in physiology 2012, 3, https://doi.org/10.3389/fphys.2012.00228.

126. Bronisz, A.; Wang, Y.; Nowicki, M.O.; Peruzzi, P.; Ansari, K.I.; Ogawa, D.; Balaj, L.; De Rienzo, G.; Mineo, M.; Nakano, I. Extracellular vesicles modulate the glioblastoma microenvironment via a tumor suppression signaling network directed by miR-1. Cancer research 2014, 74, 738-750, https://doi.org/10.1158/0008-5472.can-13-2650.

127. Nasser, M.W.; Datta, J.; Nuovo, G.; Kutay, H.; Motiwala, T.; Majumder, S.; Wang, B.; Suster, S.; Jacob, S.T.; Ghoshal, K. Down-regulation of micro-RNA-1 (miR-1) in lung cancer suppression of tumorigenic property of lung cancer cells and their sensitization to doxorubicin-induced apoptosis by miR-1. Journal of biological chemistry 2008, 283, 33394-33405, https://doi.org/10.1074/jbc.W118.004967.

128. Graner, M.W. Brain tumor exosomes and microvesicles: pleiotropic effects from tiny cellular surrogates. Molecular Targets of CNS Tumors 2011, 43-78, https://doi.org/10.5772/21478.

129. Lakhal, S.; Wood, M.J. Exosome nanotechnology: An emerging paradigm shift in drug delivery. Bioessays 2011, 33, 737-741, https://doi.org/10.1002/bies.201100076.

130. Vlassov, A.V.; Magdaleno, S.; Setterquist, R.; Conrad, R. Exosomes: current knowledge of their composition, biological functions, and diagnostic and therapeutic potentials. Biochimica et Biophysica Acta (BBA)-General Subjects 2012, 1820, 940-948, https://doi.org/10.1016/j.bbagen.2012.03.017.

131. Zhuang, X.; Xiang, X.; Grizzle, W.; Sun, D.; Zhang, S.; Axtell, R.C.; Ju, S.; Mu, J.; Zhang, L.; Steinman, L. Treatment of brain inflammatory diseases by delivering exosome encapsulated anti-inflammatory drugs from the nasal region to the brain. Molecular Therapy 2011, 19, 1769-1779, https://doi.org/10.1038/mt.2011.164.

132. Valenti, R.; Huber, V.; Iero, M.; Filipazzi, P.; Parmiani, G.; Rivoltini, L. Tumor-released microvesicles as vehicles of immunosuppression. Cancer research 2007, 67, 2912-2915, https://doi.org/10.1158/00085472.CAN-07-0520.

133. Gabrilovich, D. Mechanisms and functional significance of tumour-induced dendritic-cell defects. Nature Reviews Immunology 2004, 4, 941-952, https://doi.org/10.1038/nri1498.

134. Chistiakov, D.A.; Chekhonin, V.P. Extracellular vesicles shed by glioma cells: pathogenic role and clinical value. Tumor Biology 2014, 35, 8425-8438, https://doi.org/10.1007/s13277-014-2262-9.

135. Yang, L.; Carbone, D.P. Tumor-host immune interactions and dendritic cell dysfunction. Advances in cancer research 2004, 92, 13-27, https://doi.org/10.1016/S0065-230X(04)92002-7.

136. Kim, W.; Liau, L.M. Dendritic cell vaccines for brain tumors. Neurosurgery Clinics of North America 2010, 21, 139-157, https://doi.org/10.1016/j.nec.2009.09.005.

137. Bu, N.; Wu, H.; Sun, B.; Zhang, G.; Zhan, S.; Zhang, R.; Zhou, L. Exosome-loaded dendritic cells elicit tumor-specific CD8+ cytotoxic T cells in patients with glioma. Journal of neuro-oncology 2011, 104, 659667, https://doi.org/10.1007/s11060-011-0537-1. 
138. André, F.; Chaput, N.; Schartz, N.E.; Flament, C.; Aubert, N.; Bernard, J.; Lemonnier, F.; Raposo, G.; Escudier, B.; Hsu, D.-H. Exosomes as potent cell-free peptide-based vaccine. I. Dendritic cell-derived exosomes transfer functional MHC class I/peptide complexes to dendritic cells. The Journal of Immunology 2004, 172, 2126-2136, https://doi.org/10.4049/jimmunol.172.4.2126.

139. Misra, A.; Ganesh, S.; Shahiwala, A.; Shah, S.P. Drug delivery to the central nervous system: a review. $J$ Pharm Pharm Sci 2003, 6, 252-273.

140. Fecci, P.E.; Mitchell, D.A.; Whitesides, J.F.; Xie, W.; Friedman, A.H.; Archer, G.E.; Herndon, J.E.; Bigner, D.D.; Dranoff, G.; Sampson, J.H. Increased regulatory T-cell fraction amidst a diminished CD4 compartment explains cellular immune defects in patients with malignant glioma. Cancer research 2006, 66, 3294-3302, https://doi.org/10.1158/0008-5472.CAN-05-3773.

141. Alvarez-Erviti, L.; Seow, Y.; Yin, H.; Betts, C.; Lakhal, S.; Wood, M.J. Delivery of siRNA to the mouse brain by systemic injection of targeted exosomes. Nature biotechnology 2011, 29, 341-345, https://doi.org/10.1038/nbt.1807.

142. Thomas, A.A.; Ernstoff, M.S.; Fadul, C.E. Immunotherapy for the treatment of glioblastoma. Cancer journal (Sudbury, Mass.) 2012, 18, https://doi.org/10.1097/PPO.0b013e3182431a73.

143. Gustafson, M.P.; Lin, Y.; New, K.C.; Bulur, P.A.; O’Neill, B.P.; Gastineau, D.A.; Dietz, A.B. Systemic immune suppression in glioblastoma: the interplay between CD14+ HLA-DRlo/neg monocytes, tumor factors, and dexamethasone. Neuro-oncology 2010, 12, 631-644, se brain by systemic injection of targeted exosomes. Nature biotechnology 2011, 29, 341-345, https://doi.org/10.1093/neuonc/noq001. 